Marzena Furtak-Niczyporuk

Uniwersytet Medyczny w Lublinie

\title{
WARUNKI TRANSPORTU NIEBEZPIECZNYCH ODPADÓW MEDYCZNYCH ${ }^{1}$
}

\section{Wprowadzenie}

Mając na uwadze ochronę zdrowia i życia ludzi oraz zapobieżenie lub zmniejszenie negatywnemu wpływowi na środowisko odpadów, należy zwrócić uwagę na prawidłowy przebieg procesu gospodarowania odpadami, w tym w szczególności na transport odpadów z punktu ich wytworzenia do punktu składowania lub przetwarzania odpadów. „Odpad” to substancja lub przedmiot, których posiadacz pozbywa się, zamierza się pozbyć lub do których pozbycia się jest obowiązany. ${ }^{2}$ Przez „odpady medyczne" rozumie się odpady powstające w związku z udzielaniem świadczeń zdrowotnych oraz prowadzeniem badań i doświadczeń naukowych w zakresie medycyny. "Ś Swiadczenia zdrowotne" to działania, które służą zachowaniu, ratowaniu, przywracaniu lub poprawie zdrowia oraz inne działania medyczne wynikające z procesu leczenia lub przepisów odrębnych regulujących zasady ich wykonywania. ${ }^{4}$ Jeśli zaś chodzi o „badania naukowe”, to w sposób szczególny chodzi tu o badania stosowane, czyli prace badawcze podejmowane w celu zdobycia nowej wiedzy, zorientowane przede wszystkim na zastosowanie w praktyce. ${ }^{5}$ Wskazując na ,doświadczenia naukowe", chodzi o badania przy zastosowaniu testów i metod, w wyniku czego może dojść do opracowania nowych lub ulepszonych prac naukowych, które zastosowane będą oddziaływały na zdrowie i życie ludzi. Odpady medyczne, które powstają w związku z diagnozowaniem, leczeniem, rehabilitacją oraz profilaktyką medyczną w podmiotach leczniczych, ze względu na swoje właściwości należą do dwóch grup odpadów - komunalnych i niebezpiecznych. Najwięcej problemów

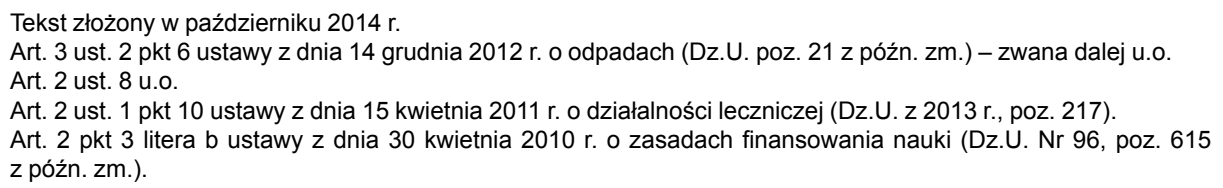


stwarzają niebezpieczne odpady medyczne, które ze względu na swoje właściwości zakaźne stanowią szczególne źródło zakażeń i chorób zakaźnych u ludzi. „Odpady niebezpieczne" charakteryzują się co najmniej jedną spośród właściwości niebezpiecznych. ${ }^{6}$ Tymczasem ,niebezpieczne odpady medyczne" to takie, które zawierają biologiczny czynnik chorobotwórczy - czyli czynnik posiadający zdolność wywoływania objawów chorobowych, drobnoustroje komórkowe lub wytwarzane przez nie produkty, zewnętrzne i wewnętrzne pasożyty człowieka lub wytwarzane przez nie produkty, cząstki bezkomórkowe zdolne do replikacji lub przenoszenia materiału genetycznego, w tym zmodyfikowane genetycznie hodowle komórkowe lub wytwarzane przez nie produkty. ${ }^{7}$ W katalogu odpadów przy grupie 18, a dokładanie podgrupie 1801 , zostały wykazane rodzaje niebezpiecznych odpadów medycznych, które dodatkowo oznaczono symbolem „ " ". Obecnie należą do nich: $180102 *$ części ciała i organy oraz pojemniki na krew i konserwanty służące do jej przechowywania; 1801 03* inne odpady, które zawierają żywe drobnoustroje chorobotwórcze lub ich toksyny oraz inne formy zdolne do przeniesienia materiału genetycznego, o których wiadomo lub co do których istnieją wiarygodne podstawy do sądzenia, że wywołują choroby u ludzi i zwierząt; $180106^{*}$ chemikalia, w tym odczynniki chemiczne, zawierające substancje niebezpieczne; $180108^{*}$ leki cytotoksyczne i cytostatyczne; 1801 10* odpady amalgamatu dentystycznego; 1801 80* zużyte kąpiele lecznicze aktywne biologicznie o właściwościach zakaźnych; $180182^{*}$ pozostałości z żywienia pacjentów oddziałów zakaźnych. ${ }^{8}$ Odpady te zawierają patogeny chorobotwórcze, związane z zawartością tkanki organicznej, czynników infekcyjnych typu biologicznego oraz niebezpiecznych substancji chemicznych pochodzących $\mathrm{z}$ leków stosowanych w leczeniu nowotworów złośliwych metodą chemiczną. ${ }^{9}$ $\mathrm{Z}$ tego też powodu odpady posiadają właściwości zakaźne, co powoduje, że podlegają zakazowi odzysku, ${ }^{10}$ dlatego też w konsekwencji są unieszkodliwiane. ${ }^{11}$

\section{Transport}

Transport niebezpiecznych odpadów medycznych został szczegółowo uregulowany prawem. Ze względu na dokonane w ostatnim czasie zmiany stanu regulacji prawnej wypada tutaj najpierw o nich wspomnieć. Tym większe ma to uzasadnie-

$6 \quad$ Art. 3 ust. 1 pkt 34 u.o.

7 Art. 2 pkt 2 ustawy z dnia 5 grudnia 2008 r. o zapobieganiu oraz zwalczaniu zakażeń i chorób zakaźnych u ludzi (Dz.U. z 2013 r., poz. 947).

8 Por. rozporządzenie Ministra Środowiska z dnia 27 września 2001 r. w sprawie katalogu odpadów (Dz.U. Nr 112, poz. 1206).

9 Szerzej M. Furtak-Niczyporuk, Organizacja unieszkodliwiania niebezpiecznych odpadów medycznych, (w:) Ocena modelu prawnego organizacji ochrony środowiska w Polsce i na Słowacji, M. Pieprzny, J. Stelmasiak, E. Ura (red.), Rzeszów 2012, s. 438.

10 Zgodnie z rozporządzeniem Ministra Zdrowia z dnia 23 grudnia 2002 r. w sprawie rodzajów odpadów medycznych i weterynaryjnych, których poddawanie odzyskowi jest zakazane (Dz.U. z 2003 r. Nr 8, poz. 103).

11 Rozporządzenie Ministra Zdrowia z dnia 23 grudnia 2002 r. w sprawie dopuszczalnych sposobów i warunków unieszkodliwiania odpadów medycznych i weterynaryjnych (Dz.U. z 2003 r. Nr 8, poz. 104 z późn. zm.). 
nie, że znajduje ciągle jeszcze zastosowanie dawna regulacja prawna w oparciu o przepisy przejściowe. ${ }^{12}$ Zasadniczo należy to odnieść do transportu drogowego niebezpiecznych odpadów medycznych, który jednak dominuje dzisiaj wyraźnie w praktyce. Niekiedy okazuje się bowiem, że transport drogowy niebezpiecznych odpadów medycznych może być kontynuowany w dotychczasowych ramach transportu drogowego odpadów niebezpiecznych. W starym stanie regulacji prawnej przepisy o przewozie drogowym towarów niebezpiecznych były bowiem stosowane odpowiednio do transportu odpadów niebezpiecznych, spełniających określone w tych przepisach kryteria klasyfikacyjne dla zaliczenia ich do jednej z klas towarów niebezpiecznych. ${ }^{13}$ Wśród klas towarów niebezpiecznych znalazły się między innymi materiały zakaźne, do jakich należy oczywiście zaliczyć także niebezpieczne odpady medyczne. Ponadto zezwolenia na transport niebezpiecznych odpadów medycznych, które zostały wydane na podstawie starej regulacji prawnej, zachowują swoją ważność na czas, na jaki zostały wydane, nie dłużej jednak niż do czasu upływu terminu do złożenia wniosku o wpis do nowego rejestru lub z dniem uzyskania wpisu do nowego rejestru, w przypadku gdy wpis nastąpił w terminie wcześniejszym. ${ }^{14}$ Tym nowym rejestrem staje się prowadzony przez marszałka województwa rejestr podmiotów wprowadzających produkty, produkty w opakowaniach i gospodarujących odpadami. ${ }^{15}$ Podmioty objęte obowiązkiem złożenia wniosku o wpis do nowego rejestru są obowiązane do złożenia tego wniosku w terminie 6 miesięcy od dnia jego utworzenia. W konsekwencji można więc stwierdzić, że uchylono dzisiaj reglamentację działalności gospodarczej odnośnie transportu niebezpiecznych odpadów medycznych, ponieważ nie jest wymagane zezwolenie, które wydawał dotąd starosta $\mathrm{w}$ formie decyzji administracyjnej. ${ }^{16}$

Nowy stan regulacji prawnej wiąże podobnie transport niebezpiecznych odpadów medycznych z transportem odpadów niebezpiecznych. ${ }^{17}$ Ponieważ nie budzi wątpliwości, że należy odpady medyczne traktować jako odpady niebezpieczne. Transport niebezpiecznych odpadów medycznych odbywa się więc z zachowaniem przepisów obowiązujących przy transporcie towarów niebezpiecznych. ${ }^{18} \mathrm{Co}$ prawda, przewidziano także delegację do wydania rozporządzenia dla ministra właściwego do spraw środowiska w porozumieniu z ministrem właściwym do spraw transportu, które ma określić szczegółowe wymagania dla transportu ogólnie rozumianych odpadów, ale trudno sobie wyobrazić uregulowanie w nim zagadnie-

Art. 250 ust. 3 u.o. w związku z art. 252 u.o.

Zob. art. 11 ust. 5 ustawy z dnia 27 kwietnia 2001 r. o odpadach (Dz.U. z 2010 r. Nr 185, poz. 1243 z późn. zm.) - zasadniczo już nieobowiązująca zwana dalej d.u.o. i wydane na jej podstawie rozporządzenie Ministra Infrastruktury z dnia 1 kwietnia 2002 r. w sprawie zakresu i sposobu stosowania przepisów o przewozie drogowym towarów niebezpiecznych do transportu odpadów niebezpiecznych (Dz.U. Nr 236, poz. 1986 z późn. zm.).

Art. 233 ust. 1 u.o.

Art. 49 ust. 1 u.o.

Art. 28 d.u.o.

Art. 24 u.o.

Art. 24 ust. 2 u.o. 
nia transportu odpadów niebezpiecznych z uwagi na wcześniejsze tutaj odesłanie do przepisów o transporcie towarów niebezpiecznych. ${ }^{19}$ Przy tym wypada jeszcze zauważyć, że nie zostało to rozporządzenie do tej pory wydane. W związku z tym transport niebezpiecznych odpadów medycznych musi dalej zostać utożsamiony z przewozem towarów niebezpiecznych. Zatem dochodzi do utożsamienia z jednej strony pojęć „,transport” i ,przewóz”, a z drugiej strony pojawia się utożsamienie pojęć „odpad niebezpieczny” i „towar niebezpieczny”. Takie stanowisko wynika z interpretacji użytego zwrotu „odbywa się z zachowaniem przepisów”, co wskazuje na ich stosowanie bezpośrednio, a nie stosowanie odpowiednio według zasad techniki prawodawczej. Samo pojęcie „transport odpadów” nie ma nawet definicji legalnej, gdyż miałaby ona najwyżej charakter sprawozdawczy, skoro nie ma potrzeby wprowadzania jego szczególnego znaczenia. Zatem transport odpadów należy tutaj rozumieć jako pewną usługę, do której stosuje się określone przepisy ogólne dotyczące przewozu i przepisy szczególne związane z określonymi konkretnie rodzajami przewozu (drogowego, kolejowego, rzecznego, lotniczego). ${ }^{20}$

\section{Europejska umowa dotycząca przewozu drogowego towarów niebezpiecznych}

Transport niebezpiecznych odpadów medycznych jest zasadniczo oparty na przewozie drogowym towarów niebezpiecznych. W konsekwencji znajdują tutaj zastosowanie przepisy ustawowe o przewozie towarów niebezpiecznych i przepisy umowy europejskiej dotyczącej przewozu drogowego towarów niebezpiecznych, która jest powszechnie znana jako ADR. ${ }^{21}$ Przepisy ustawowe o przewozie towarów niebezpiecznych mają zwykle charakter ramowy, ze względu na bardzo częste odesłanie $\mathrm{w}$ istotnych sprawach do ADR i wprowadzanie jedynie uzupełnień w stosunku do ADR. W konsekwencji jedynym systemem przewozu odpadów niebezpiecznych po drogach wdrożonym kompleksowo, który zarazem spełnia wymagania Organizacji Narodów Zjednoczonych i obowiązuje w Unii Europejskiej, szczególnie odnośnie zapewnienia bezpieczeństwa, okazuje się przede wszystkim regulacja prawna zawarta dzisiaj w ADR. W tym kontekście należy ogólnie teraz wskazać na przepisy ustawowe o przewozie towarów niebezpiecznych odsyłające do ADR. Tak więc przepisów ustawowych o przewozie towarów niebezpiecznych nie stosuje się do przewozu towarów niebezpiecznych w przypadkach wskazanych

\footnotetext{
Art. 24 ust. 7 u.o.

Zob. W. Radecki, Ustawa o odpadach. Komentarz, Warszawa 2013, s. 145.

Zob. ustawę z dnia 19 sierpnia 2011 r. o przewozie towarów niebezpiecznych (Dz.U. Nr 227, poz. 1367 z późn. zm.) - zwana dalej u.p.t.n. oraz umowę europejską dotyczącą międzynarodowego przewozu drogowego towarów niebezpiecznych (ADR), sporządzoną w Genewie dnia 30 września 1957 r. (Dz.U. z 2011 r. Nr 110, poz. 641), wraz ze zmianami obowiązującymi od dnia ich wejścia w życie w stosunku do Rzeczypospolitej Polskiej, ogłoszonymi we właściwy sposób - zwana dalej ADR.
} 
w ADR. ${ }^{22} \mathrm{~W}$ sprawach nieuregulowanych przepisami ustawowymi o przewozie towarów niebezpiecznych, w tym do środków transportu i urządzeń transportowych, stosuje się ostatecznie przepisy ADR. ${ }^{23}$ Następnie zezwala się na przewóz towarów niebezpiecznych, określonych w ADR jako towary dopuszczone do przewozu, wyłącznie na warunkach określonych w przepisach ADR. ${ }^{24}$ Wreszcie zabrania się przewozu towarów niebezpiecznych określonych w ADR jako towary niedopuszczone do przewozu. ${ }^{25}$

Zgodnie z wymogami ADR materiały zakaźne, które zawierają substancje zakaźne lub inne substancje, które powodują choroby u ludzi i zwierząt podlegają przepisom ADR. Niebezpieczne odpady medyczne, zgodnie z ADR, zostały przypisane do klasy 6.2 pod nazwą ,Materiały zakaźne” i są to materiały, o których wiadomo lub co do których istnieje uzasadnione podejrzenie, że zawierają drobnoustroje chorobotwórcze, takie jak: bakterie, wirusy, riketsje, mikoplazmy, pasożyty i grzyby oraz inne czynniki, takie jak priony, które mogą powodować choroby u ludzi lub u zwierząt. ${ }^{26}$ Materiały zakaźne w tej klasie należą do dwóch kategorii: A - która obejmuje materiały zakaźne, które przewożone są w takiej postaci, że kontakt z nimi może spowodować inwalidztwo, zagrożenie życia lub chorobę śmiertelną, pojawiającą się u dotychczas zdrowych ludzi lub zwierząt (kontakt następuje wówczas, gdy po uwolnieniu materiału zakaźnego na zewnątrz opakowania zabezpieczającego dochodzi do kontaktu fizycznego z człowiekiem lub zwierzęciem); B - która zalicza materiały zakaźne niespełniające warunków kategorii A. W tym miejscu należy podkreślić, że jeżeli istnieje wątpliwość, czy dany produkt zawiera materiał zakaźny, z którym kontakt może negatywnie wpłynąć na zdrowie lub życie ludzi albo zwierząt, wówczas powinien być on zaliczony do kategorii A. Materiały w tej klasie posiadają numer rozpoznawczy UN, który został odpowiednio przydzielony dla materiałów zakaźnych w czterech pozycjach, jako: nr UN 2814 materiał zakaźny dla ludzi (próbki od chorych lub odpady medyczne lub kliniczne, które zawierają materiał zakaźny kategorii A); nr UN 2900 materiał zakaźny dla zwierząt; nr UN 3291 odpady medyczne lub kliniczne (wyłącznie takie, co do których wiadomo, że istnieje małe prawdopodobieństwo, że zawierają materiały zakaźne); nr UN 3373 materiał biologiczny niespełniający warunków kategorii A. Należy zatem wskazać na wyłączenia w stosowaniu tu przepisów ADR w sytuacjach, gdy: materiał nie zawiera substancji zakaźnych lub innych substancji, które nie powodują chorób u ludzi i zwierząt; materiał zawiera drobnoustroje, ale takie, które nie są patogenne dla ludzi lub zwierząt; materiał w postaci, w której obecne w nich patogeny zostały zneutralizowane lub zdezaktywowane w taki sposób, że nie stwarzają już zagrożenia

Art. 3 ust. 1 u.p.t.n.

Art. 4 u.p.t.n.

Art. 5 ust. 1 u.p.t.n.

Art. 5 ust. 2 u.p.t.n.

Tom I, część 2, dział 2.2.62 ADR. 
dla ludzi; materiał, w którym stężenie patogenów występuje na naturalnym poziomie i które uważane są za niestwarzające znacznego zagrożenia zakaźnego; wyroby medyczne lub sprzęt medyczny, potencjalnie zawierające materiał zakaźny, które są transportowane w związku z koniecznością przeprowadzenia zabiegów dezynfekcji, czyszczenia, sterylizacji, naprawy lub przeglądu; odpady medyczne, co do których nie istnieje obowiązek zbierania i usuwania, a więc takie odpady, które nie podlegają przepisom szczególnym dotyczącym zapobiegania infekcjom; unieszkodliwione odpady medyczne, które uprzednio zawierały materiał zakaźny. Jednocześnie dodać należy, że przewożony materiał biologiczny w próbkach diagnostycznych lub klinicznych, jak też wyroby medyczne i sprzęt medycznych transportowany do zabiegów odkażania $\mathrm{z}$ drobnoustrojów chorobotwórczych, muszą być zapakowane w opakowania skonstruowane i zbudowane w taki sposób, że w normalnych warunkach przewozu nie ulegną uszkodzeniu, przebiciu lub nie powstanie wyciek ich zawartości, a w przypadku zrzutu z wysokości 1,2 m zachowają swoją wytrzymałość. Wskazane wyjątki, w przypadku których nie ma zastosowania wykładania ADR, należy zatem traktować jak zwykły transport materiałów.

W sposób szczególny należy zapewnić bezpieczeństwo podczas przewozu materiału zakaźnego dla ludzi o nr UN 2814, który w tej grupie odnosi się zarówno do próbek od chorych, czyli materiału pobranego od ludzi przewożonych do celów diagnostycznych, leczniczych, jak też badań naukowych oraz niebezpiecznych odpadów medycznych, które powstały podczas badania lub leczenia ludzi, lub z doświadczeń naukowych, a które to odpady zawierają biologiczny czynnik chorobotwórczy. Materiał objęty tą grupą został sklasyfikowany jako towar niebezpieczny dużego ryzyka, czyli taki towar, który użyty niezgodnie ze swoim przeznaczeniem, może powodować poważne, negatywne następstwa dla zdrowia i życia ludzi. ${ }^{27} \mathrm{~W}$ sposób szczególny rozważania zostaną skoncentrowane wokół opakowania i transportowania niebezpiecznych odpadów medycznych. Na szczególną uwagę zasługuje tutaj etap opakowania niebezpiecznych odpadów medycznych. „Opakowanie” oznacza jeden lub więcej pojemników oraz inne elementy lub materiały potrzebne do zapewnienia ich integralności oraz spełniania przez nie funkcji ochronnych wobec zawartości. Jednak należy tu pamiętać, że odpowiednie opakowanie niebezpiecznych odpadów medycznych jest uzależnione od rodzaju odpadu. ${ }^{28}$ I tak odpady, takie jak części ciała i organy oraz pojemniki na krew i konserwanty służące do jej przechowywania oraz inne odpady, które zawierają żywe drobnoustroje chorobotwórcze lub ich toksyny oraz inne formy zdolne do przeniesienia materiału genetycznego, a także pozostałości z żywienia pacjentów oddziałów zakaźnych, należy zbierać do worków jednorazowego użycia, wykonanych z folii polietylenowej z możliwością jednorazowego zamknięcia. Worki te z uwagi na ich zawartość mają kolor czerwony,

27 Tom I, część 1, dział 1.10.3 ADR.

28 Zgodnie z rozporządzeniem Ministra Zdrowia z dnia 30 lipca 2010 r. w sprawie szczegółowego sposobu postępowania z odpadami medycznymi (Dz.U. Nr 139, poz. 940) - zwanym dalej r.s.s.p.o.m. 
nieprzezroczysty, który jednocześnie oznacza realne niebezpieczeństwo i stan najwyższej ostrożności przy kontakcie z jego zawartością. Przede wszystkim worki te muszą być wykonane $\mathrm{z}$ materiałów odpornych na działanie wilgoci, środków chemicznych oraz wytrzymałych na oddziaływanie mechaniczne. Dalej określone odpady, jak: chemikalia, w tym odczynniki chemiczne, zawierające substancje niebezpieczne, leki cytotoksyczne i cytostatyczne oraz odpady amalgamatu dentystycznego, należy zbierać w worki koloru żółtego, o właściwościach analogicznych, jak dla wyżej opisanych odpadów. Należy jednak zaznaczyć, że odpady we wszystkich omówionych tu grupach, jeżeli są o ostrych końcach i krawędziach, jak na przykład: igły, skalpele, należy je bezwzględnie zbierać do pojemników, wykonanych z możliwością tylko jednokrotnego zamknięcia, uniemożliwiających jakikolwiek ubytek ich zawartości. Pojemniki jednorazowego użycia mają być wykonane ze sztywnego tworzywa, o dobrej jakości, mechanicznie odporne na przekłucie bądź przecięcie, tak aby zapewnić bezpieczeństwo osób je przenoszących. Ponadto pojemniki te mają zapewnić wytrzymałość na wstrząsy, wibracje, zmiany temperatury, wilgotności lub ciśnienia, chociażby podczas ich transportu. Dodatkowo pojemniki mają swoje kolory, odpowiednio do zawartości rodzajów odpadów, które zawierają. Zatem opakowania przeznaczone do przechowywania niebezpiecznych odpadów medycznych muszą być zgodne z wymaganiami ADR dotyczącymi konstrukcji oraz badania opakowań dla materiałów zakaźnych kategorii A klasy 6.2, a w szczególności z normą ISO 16106:2006. ${ }^{29}$ Muszą one być wykonane z materiałów, które przy bezpośrednim kontakcie z zawartością będą odporne na ich zniszczenie lub znaczne osłabienie, a także nie zawierają w swoim składzie groźnych domieszek, które mogłyby wejść w reakcje $\mathrm{z}$ ich zawartością bądź też tworzyć niebezpieczne związki. Jednocześnie materiały o nr. UN 2814, w tym też niebezpieczne odpady medyczne nie powinny być pakowane razem z innymi towarami, o czym świadczą zalecenia MP5 zgodnie z ADR. $^{30}$

Po odpowiednim opakowaniu niebezpiecznych odpadów medycznych, w worek czy też pojemnik, należy w widocznym miejscu umieścić oznakowanie, co do identyfikacji zawartości, które musi zwierać trzy podstawowe elementy: kod odpadów w nich przechowywanych, adres lub siedzibę wytwórcy odpadów oraz datę zamknięcia. ${ }^{31}$ Oczywiście odpowiednie opakowanie niebezpiecznych odpadów medycznych ma także swoje odzwierciedlenie w procedurze ich przewozu zgodnie z ADR, gdzie określone są stosowane instrukcje w tym zakresie. I tak pakowanie niebezpiecznych odpadów medycznych należy do II grupy pakowania zgodnie z ADR, gdzie co do zasady materiał stwarza średnie zagrożenie. Dla materiałów przewożonych o nr. UN 2814 stosuje się instrukcje pakowania P620, gdzie dla niebezpiecznych odpadów medycznych jednak mają tu zastosowanie przepisy szcze-

Tom II, część 6, dział 6.3 ADR.

Tom II, część 4, dział 4.1.10 ADR.

Zgodnie z § 4 r.s.s.p.o.m. 
gólne. ${ }^{32}$ Dodatkowo przepisy ADR wymagają, aby na każdej sztuce transportowanej przesyłki umieścić stosowne oznakowanie ostrzegawcze - nalepkę odnoszącą się do klasy zagrożenia, która musi być zgodna co do koloru, symboli i formatu. I tak znak ten posiada w górnej części symbol - trzy półksiężyce nałożone na koło, a w dolnym narożniku cyfrę „6" wskazującą na klasę zagrożenia. Zarówno symbol, jak i cyfra są koloru czarnego na białym tle. Dodatkowo w dolnej połowie znaku można zamieścić napis „Materiał zakaźny” oraz „W razie uszkodzenia lub wycieku natychmiast powiadomić służby medyczne". Każda nalepka musi być umieszczona na tej samej stronie sztuki przesyłki, tak aby nie była ona zakryta lub zasłonięta. Jeżeli nieregularny kształt lub małe wymiary sztuki przesyłki uniemożliwiają odpowiednie umieszczenie na niej nalepki, to może być ona umieszczona na dobrze zamocowanej przywieszce. Nalepki muszą być wykonane z materiałów odpornych na zewnętrzne warunki atmosferyczne. Zamiast nalepek może być stosowane nieścieralne oznakowanie ostrzegawcze, odpowiadające dokładnie wymaganiom na wzorze nalepki.

Niezbędnym elementem każdego przewozu niebezpiecznych odpadów medycznych jest dokument przewozowy, który zawiera informacje dotyczące każdego materiału i przedmiotu przeznaczonego do przewozu, w szczególności są to: numer UN; prawidłowa nazwa przewozowa i następująca po niej uzupełniająca nazwa techniczna, która podana jest w nawiasie; nr wzoru nalepek lub nr klasy materiału; grupa pakowania, przypisana do danego materiału, która może być poprzedzona literami „PG” lub literami odpowiadającymi wyrazom „Grupa Pakowania”; liczba i określenie sztuk przesyłki; całkowita liczba każdego z towarów niebezpiecznych mającego odrębny numer UN; nazwa i adres nadawcy; nazwa i adres odbiorcy (odbiorców) oraz dodatkowo imię, nazwisko i numer telefonu osoby odpowiedzialnej; kod ograniczeń przewozu przez tunele (kod ten jest podawany, jeżeli został przypisany lub gdy przewidywana trasa przewozu przebiega przez tunele, w których obowiązują ograniczenia przewozu towarów niebezpiecznych). ${ }^{33}$ Umiejscowienie i kolejność informacji wymaganych $\mathrm{w}$ dokumencie przewozowym jest następująca: numer UN, prawidłowa nazwa przewozowa, nr wzoru nalepek, grupa pakowania, kod ograniczeń przewozu przez tunele. Pozostałe informacje już w dowolnej kolejności także znajdują się w dokumencie przewozowym. Dodatkowo mają tu zastosowanie także przepisy szczególne dotyczące odpadów, które określają, że prawidłowa nawa przewozowa powinna być poprzedzona wyrazem „ODPAD”. Mając powyższe na uwadze prawidłowa informacja o przewożonym materiale, $w$ tym przypadku niebezpiecznych odpadach medycznych, która jest wymagana w dokumencie przewozowym jest następująca „UN 2814 ODPAD MATERIAŁ ZAKAŹNY DLA LUDZI, 6.2 PG II, (E)”. Jeżeli przewożone materiały zakaźne są nieznane, ale jest podejrzenie, że spełniają kryteria pozwalające włączyć je do kategorii A i zaliczyć do UN 
2814, to określenie „materiały zakaźne podejrzewane o przynależność do kategorii A" powinno być ukazane w dokumencie przewozowym w nawiasach, następujących po prawidłowej nazwie przewozowej. ${ }^{34}$

Najważniejszym aspektem jest tu zapewnienie bezpiecznego transportu niebezpiecznych odpadów medycznych, czyli takiego przewiezienia odpadów, aby zapewnić bezpieczeństwo dla ludzi i środowiska. Jednostki transportowe dopuszczone do przewozu niebezpiecznych odpadów medycznych to zgodnie z ADR pojazdy zamknięte lub kontenery zamknięte, które nie mogą zawierać więcej niż jednej przyczepy lub naczepy. Najczęstszym przewozem towarów niebezpiecznych, w tym niebezpiecznych odpadów medycznych jest przewóz drogowy, poprzez ich przemieszczenie pojazdem po drodze publicznej lub innych drogach ogólnodostępnych z uwzględnieniem postojów wymaganych podczas tego przewozu oraz innych czynności związanych z tym przewozem. ${ }^{35}$ Należy tu także zwrócić szczególną uwagę na obowiązujące w ADR warunki dotyczące załadunku i rozładunku niebezpiecznych odpadów medycznych. Obowiązują tu zasady obejmujące następujące sytuacje: jakikolwiek materiał wydostał się z opakowania i rozsypał wewnątrz pojazdu lub kontenera, to do czasu ich dokładnego oczyszczenia, a w razie potrzeby dezynfekcji lub odkażania, pojazd lub kontener nie może być ponownie użyty (ewentualne wszystkie inne materiały czy przedmioty przewożone w tym pojeździe lub kontenerze powinny być wówczas sprawdzone pod kątem skażenia); drewniane części pojazdu lub kontenera, które miały kontakt z tymi materiałami powinny być usunięte i spalone; sztuki przesyłki powinny być tak rozmieszczone, aby były łatwo dostępne; w przypadku, gdy sztuki przesyłki mają być przewożone w temperaturze otoczenia nie wyższej niż $15^{\circ} \mathrm{C}$ lub w stanie schłodzenia, należy zapewnić możliwość utrzymania odpowiedniej temperatury w czasie rozładunku i składowania; sztuki przesyłki powinny być składowane tylko w miejscach chłodnych, oddalonych od źródeł ciepła; należy przedsięwziąć szczególne środki ostrożności przy ewentualnym kontakcie przewożonego materiału z żywnością, artykułami spożywczymi i karmą dla zwierząt. ${ }^{36}$ Oznakowanie jednostek transportowych przewożących niebezpieczne odpady medyczne także wymaga zastosowania oznakowania bezpieczeństwa zgodnie z nalepkami na transportowanych przesyłkach. Chodzi tu o zamieszczenie na jednostkach transportowych, odpowiednio na pojeździe lub na zewnętrznej powierzchni kontenerów nalepki zgodnej co do kształtu, symbolu, oznaczeń cyfrowych i graficznych, jak na transportowanych przesyłkach. Oznaczenie to powinno być umieszczone na obu bokach oraz z tyłu pojazdu. Jednostki transportowe przewożące niebezpieczne odpady medyczne, powinny być zaopatrzone w dwie prostokątne tablice barwy pomarańczowej, umieszczone w płaszczyźnie pionowej. Jedna tablica powinna być przymocowana z przodu, a druga z tyłu jednostki transportowej,

Przepisy szczególne 318 tom I, część 3, dział 3.3 ADR.

Art. 2 pkt 5 u.p.t.n.

Przepisy szczegółowe dotyczące przewozu odpowiednio CV13, CV26, CV25, CV28 ADR. 
obie prostopadle do osi podłużnej tej jednostki. Jeżeli przyczepa zawierająca niebezpieczne odpady medyczne została odłączona od pojazdu samochodowego w trakcie przewozu, to tablica barwy pomarańczowej musi pozostać z tyłu przyczepy. Tablice te powinny być zaopatrzone w numer rozpoznawczy zagrożenia (2- lub 3-cyfrowy), pod którym znajduje się numer UN (4-cyfrowy). W przypadku przewozu niebezpiecznych odpadów medycznych wymagany numer rozpoznawczy zagrożenia to 606 (materiał zakaźny) oraz numer UN 2814. Zamieszczenie tablic powinno zapewnić ich trwałość podczas transportu oraz być dobrze widoczne. Tablice barwy pomarańczowej powinny mieć właściwości odblaskowe i rozmiary: szerokość 40 $\mathrm{cm}$ i wysokość $30 \mathrm{~cm}$ oraz powinny być otoczone czarnym obrzeżem o szerokości $15 \mathrm{~mm}$. Dodatkowo numery rozpoznania zagrożenia i numer UN powinny być naniesione czarnymi cyframi o wysokości $100 \mathrm{~mm}$ i grubości $15 \mathrm{~mm}$. Materiał użyty do wytworzenia tablicy powinien być ognioodporny i odporny na warunki atmosferyczne oraz zapewniać trwałość oznakowania.

Mamy tu jednak jeszcze jeden aspekt związany z zapewnienia bezpiecznego transportu niebezpiecznych odpadów medycznych, który dotyczy uczestników przewozu. Chodzi tu w szczególności o przewoźnika wykonującego czynności związane z przewozem towarów niebezpiecznych. Przewoźnik ma obowiązek przedsięwziąć niezbędne środki bezpieczeństwa odpowiednie do natury i zakresu dających się przewidzieć zagrożeń, w celu zapobieżenia szkodom i urazom oraz, jeżeli jest to wskazane, w celu zminimalizowania ich skutków. Oczywiście te szczególne warunki bezpieczeństwa przy przewozie towarów niebezpiecznych, musi zapewnić przewoźnik lub osoby przez niego zatrudnione, których obowiązki dotyczą przewozu towarów niebezpiecznych. Przewoźnik, który zleca podjęcie w jego imieniu czynności przewozowych, najpierw musi osobę, wykonującą obowiązki przewozu niebezpiecznych odpadów medycznych, przeszkolić w zakresie jej odpowiedzialności i obowiązków. Chodzi tu o szkolenie ogólne, szkolenie stanowiskowe oraz szkolenie z zakresu bezpieczeństwa odnoszące się między innymi do rodzajów zagrożeń związanych z przewozem towarów niebezpiecznych, podjęcia czynności po zaistnieniu wypadku, w tym w zakresie pierwszej pomocy, bezpieczeństwa ruchu drogowego, używania sprzętu ochronnego oraz odpowiedzialności cywilnej, administracyjnej i karnej. ${ }^{37} \mathrm{~W}$ związku z tym czynności, które nie były objęte ukończonym szkoleniem osoba przewożąca niebezpieczne odpady medyczne może wykonywać wyłącznie pod bezpośrednim nadzorem osoby przeszkolonej. Dokumentem potwierdzającym przeprowadzenie szkolenia jest zaświadczenie ADR. Podkreślić tu należy, że szkolenia te powinny być okresowo uzupełniane w celu uwzględnienia zmian w przepisach dotyczących przewozu. Zaświadczenie ADR potwierdzające odbycie takiego szkolenia jest jednym z wymaganych dokumentów przez osobę wykonującą przewóz towarów niebezpiecznych. Ważne są tu wskazane przez ADR obowiązki 
spoczywające na przewoźniku, który powinien przed rozpoczęciem przewozu w szczególności: upewnić się, że towary niebezpieczne przeznaczone do przewozu są dopuszczone do przewozu zgodnie z ADR; upewnić się, że wszystkie informacje określone przez ADR są dostarczone przed rozpoczęciem przewozu, w tym wymagane dokumenty; sprawdzić wzrokowo, czy pojazd i ładunek nie mają oczywistych wad oraz czy nie występują wycieki lub nieszczelności, braki w wyposażeniu; upewnić się, że nie upłynął nieprzekraczalny termin następnego badania technicznego pojazdu; sprawdzić, czy pojazd nie jest nadmiernie załadowany; upewnić się, że na pojazdach umieszczone zostało wymagane oznakowanie i nalepki ostrzegawcze; upewnić się, że w pojeździe znajduje się wyposażenie wymienione w pisemnych instrukcjach dla kierowcy. Jeżeli wykonując powyższe czynności przewoźnik stwierdzi naruszenie wymagań ADR, to nie powinien on rozpocząć przewozu do czasu usunięcia stwierdzonych naruszeń. Wymienione działania mają upewnić przewoźnika niebezpiecznych odpadów medycznych, że zachowane są wszystkie środki bezpieczeństwa dla życia i zdrowia ludzi oraz ochrony środowiska, a także spełnione są wymagania w przypadku ewentualnej kontroli. W przypadku nieprawidłowości wykrytych podczas kontroli może dojść do unieruchomienia pojazdu, do czasu podjęcia działań naprawczych mających na celu doprowadzenie pojazdu do stanu wymaganego i nałożenia kar w związku z wykrytym naruszeniem.

\section{Podsumowanie}

Przepisy szczegółowe ADR wskazują, że ma tu zastosowanie ograniczenie dla jednostek transportowych poruszających się po drogach, które dotyczy tutaj przepisów prawa ruchu drogowego, a szczególnie zakazu przejazdu przez tunele kategorii E, jeżeli przewożone ilości przekraczają 8 ton całkowitej masy brutto na jednostkę transportową. Dodatkowo występują tu także wymagania dodatkowe, co do postępowania podczas postojów jednostki transportującej niebezpieczne odpady medyczne, dokładnie podczas przewozu tych odpadów dopuszczalne są krótkie postoje na potrzeby służbowe, jednak z zastrzeżeniem, że nie powinny się one odbywać w pobliżu miejsc zamieszkałych lub uczęszczanych przez ludzi - dłuższe postoje w pobliżu takich miejsc są dozwolone wyłącznie za zgodą właściwych władz. ${ }^{38} \mathrm{~W}$ sposób szczególny należy także zapewnić nadzór jednostce transportującej niebezpieczne odpady medyczne podczas zaparkowania w magazynie lub podobnych miejscach na terenie przedsiębiorstwa, gdzie należy zapewnić im bezwzględne bezpieczeństwo. W razie braku takich warunków, po odpowiednim zabezpieczeniu pojazdu, może on być zaparkowany w wydzielonym miejscu - na parkingu samochodowym nadzorowanym przez personel, który został poinformowany o właściwościach ładunku i miejscu pobytu kierowcy lub gdy są niedostępne takie miejsca, pojazd można zaparkować 
na publicznym lub prywatnym parkingu samochodowym, gdzie pojazd nie jest narażony na uszkodzenie za strony innych pojazdów lub też jeżeli w pierwszym i drugim przypadku nie są dostępne wolne miejsca parkingowe pojazd z niebezpiecznymi odpadami medycznymi może zostać zaparkowany w odpowiednim miejscu położonym na otwartym terenie, oddzielonym od głównych dróg i budynków mieszkalnych, gdzie w normalnych warunkach nie przechodzą i nie gromadzą się ludzie. ${ }^{39}$ Chodzi tu o zabezpieczenie przewożonego ładunku przed nieuprawnionym rozładunkiem i zapewnienie bezpieczeństwa dla miejsca i ludzi. 
CONDITIONS FOR THE TRANSPORT OF HAZARDOUS MEDICAL WASTE

An inherent element of granting health care services, or conducting research and scientific studies is the accumulation of hazardous medical waste that can cause infections and infectious diseases in humans and create a danger to the environment. A particularly important step in the management of this waste is its safe transportation from the place of production to the place of disposal. The transportion of hazardous medical waste by road is essentially based on laws on the transportation of hazardous goods, but also to be considered are the provisions of the European Agreement concerning the carriage of hazardous goods by road, commonly known as ADR. Therefore, transportation of the waste is also associated with its proper packing in suitably labeled bags or containers, its carriage in suitable vehicles bearing the appropriated hazard warning symbols and its safe mobility on public roads.

Keywords: health care services, dangerous medical waste, safe transport 